\title{
THE PROBLEM OF GRANTING VOTING RIGHTS TO BONDHOLDERS
}

\author{
Jomn Evarts Tracy*
}

$\mathrm{D}$ URING the past few years there have been a large number of defaults in the payment of the fixed obligations of corporations, mostly in the payment of bonds secured by trust mortgages. In the endeavor to protect and enforce the rights of the security holders the bar have encountered serious problems, both of substance and of procedure, which render it extremely difficult, in many cases, to insure the results desired by the clients, viz. (I) the sequestration of the rents and profits of the defaulting corporation, so that the same may be available for payment on the defaulted obligations, and (2) the realization upon the property mortgaged as security for such obligations. Most of such diffculties appear to be inherent in our system of procedure for enforcing the rights of holders of defaulted securities and suggestions are continually being made for the improvement of that procedure or for the adoption of a new procedure which will avoid some or all of the difficulties so encountered.

Before we undertake to consider the soundness of these new proposals it may be well to briefly consider the difficulties which are encountered in following present practices.

One difficulty arises out of the fact that the rents and profits from the mortgaged property, which are normally pledged as additional security under the mortgage, cannot effectively be sequestered for the benefit of the bondholders without the appointment of a receiver.

There are many reasons for wishing to avoid a receivership: In the first place, it is expensive to the bondholders, for, before the bondholders can realize anything from the revenues so sequestered, there must be paid the compensation and expenses of the receiver and of his counsel, often running into substantial sums. In the second place, the receivership, if it be of the property of a manufacturing or mercantile corporation, cannot but result in harm to the business of the corporation. Not only will its credit be affected, so that it will often have to obtain new and difficult current financing for the conduct of its operations, but long time contracts that might otherwise go to it will be diverted to competitors in the busi-

* Professor of Law, University of Michigan Law School. 
ness, for who will wish to undertake the risk of entering into a long time contract with a concern, the receivership of which indicates that it may soon be forced to discontinue its business operations altogether?

In the third place, a suit for the appointment of a receiver under a trust mortgage commits the bondholders to a practically irrevocable course of action, for preparatory to such suit the bonds will have had to be assembled by a protective committee, the payment of the principal of the bonds will generally have been accelerated by notice served, and the bill of complaint will be one for foreclosure, with the receivership as only an ancillary remedy. In such a case it is almost impossible for the bondholders to temporize with the situation and to ever retrace their steps, even though business conditions affecting the property might materially change after the suit is brought.

Also, under modern conditions the assembling of the bonds for suit is no longer a simple matter of communicating with bondholders and obtaining their deposits of securities, but the task must be attended to of complying with the complicated and detailed provisions of the Federal Securities Act, for a certificate of deposit for a bond is a security which must be registered with the Securities and Exchange Commission under the terms of that Act. Under former rulings no such certificate of deposit could be issued until there had been registered with the Commission a proposed plan of reorganization." While such requirement is no longer in effect, the task of registration is still a difficult one, in view of the changes which are constantly being made in the rules and regulations of the Commission. Also the news item as to registration gives publicity to the difficulties which the debtor corporation has encountered, which publicity cannot but be harmful to its business.

The next set of difficulties encountered by the bondholders are in connection with the acquisition of the mortgaged property at the foreclosure sale.

One difficulty is that in those jurisdictions where there is a statutory period of redemption it is usually impossible for the purchaser to obtain possession of the property until the expiration of such redemption period, thereby delaying, for a long time, quite often a year or fifteen months, any opportunity to take over and reorganize the business for the benefit of the bondholders. ${ }^{3}$

Another difficulty (or set of difficulties, for they are many) arises out of

${ }^{2} 48$ Stat. 74 , I5 U.S.C.A. $\$ 77 \mathrm{~b}$ (I) (I933).

- Federal Trade Commission, Securities Division, Form D-r.

3 Brine v. Hartford Fire Ins. Co., 96 U.S. 627 ( 1877 ). 
the fact that only in rare instances can all the bondholders be united in any reorganization plan. Provision must therefore be made in the plan not only for the raising of cash to take care of the expenses of the receivership and the foreclosure, but for paying off in cash such bondholders as do not elect to participate in the reorganization by accepting new securities under the plan. This last named problem becomes more difficult when it is encountered in those jurisdictions where there is a statutory period of redemption after foreclosure sale, for the danger of having the property redeemed by the mortgagor or by a subsequent creditor for the amount bid, if a lesser sum is bid than the amount due on the mortgage indebtedness, requires that the bid made be sufficiently large to insure against probable redemption. On the other hand, the larger the bid the more money will have to be provided for the cash payment for non-participating bondholders. Also the prospect of obtaining such cash distribution will seriously increase the number of hold-outs, who will prefer to take their distributive shares in cash rather than to participate in the reorganization. ${ }^{4}$

An even more difficult set of problems is encountered where the fixed obligations of the corporation on which realization is sought are not mortgage bonds but unsecured debentures. In such a case the obligations constitute no lien on the debtor's assets and represent only the right to participate pari passu with other unsecured creditors in the distribution of the assets of the insolvent. Suit on the debentures is at law rather than in equity and carries with it no right to the appointment of a receiver. While such action at law is going its ordinary course, the debtor will remain in possession of its property and business, applying the earnings thereof as it seems best. Theoretically, such action will result in a judgment and levy, followed by an execution sale, but, as a practical matter, this will not be permitted by the other creditors, and the general result will be that the corporation will be thrown into bankruptcy and the rights of the debenture holders will have to be worked out as general creditors (although usually the majority creditors) in a bankruptcy proceeding, with the destruction of the business of the corporation which is generally consequent upon its adjudication as a bankrupt.

The above are certain of the difficulties that are encountered in the effort to protect the interests of the holders of the fixed obligations of corporations, whether they be mortgage bonds or unsecured debentures. Of the many proposals that have been made for changes in procedure which will avoid those difficulties, the writer will discuss the one which appears to him to have the most merit, not with the idea of arriving at any fixed

\footnotetext{
4 Tracy, Corporate Foreclosures, Receiverships and Reorganizations (I929), 230.
} 
conclusion as to its adoption by clients as a solution of all their difficulties, but of stimulating general discussion on the subject by those who may see strength or weakness in the plan proposed. ${ }^{5}$

The proposal is that a corporation which is about to put out an issue of fixed obligations, whether they be mortgage bonds or unsecured debentures, be required to grant to the holders of such securities, in the event of a default, the right to vote at corporate elections and to have the controlling vote, so that they will then have the complete management of the corporation, with the right to operate the business and to apply the income therefrom to the payment of the amounts due on such obligations until all defaults shall have been made good, whereupon the right of security holders to vote will cease and the voting control will revert to the shareholders. ${ }^{6}$ Under this plan no receivership of the property of the corporation would be necessary, as the security holders would already have the revenues of the corporation and the income from the mortgaged property exclusively within their control.7

$s$ The proposal is not altogether novel, for it has, from time to time, been the subject of discussion among lawyers interested in foreclosure problems, but the argument that it should now be put into practical use in order to avoid the many difficulties in the present procedure which have been disclosed by the experience of counsel during the late depression, has been brought to the attention of the writer by Roger B. Keeney, Esq., of the Grand Rapids, Michigan, bar, to whom the writer is indebted for many very interesting and helpful expressions of his views on the subject. Many times in this article the writer will refer to the views of Mr. Keeney on various of the problems involved.

${ }^{6}$ The question naturally arises, "Why not grant to the security holders the sole vote in the event of default?" Mr. Keeney's position is that it would be much better to provide only that the security holders may elect a majority of the directors, not only so that the shareholders may still retain an interest in the management and share responsibility for managerial policies agreed to by all, but that under some state statutes it is questionable whether voting rights granted to security holders may be in lieu of the inherent voting privileges of shareholders. The method of conferring such majority voting rights will be later discussed.

7 Quaere:-That would apparently be so as to the income which is received and applied by the corporation to the mortgage debt during the time when the bondholders are in voting control. But what if a receivership or bankruptcy should issue? Would the bondholders have a lien on those funds in the possession of the receiver or the trustee in bankruptcy representing income collected but unexpended during the period in which the bondholders were in voting control of the corporation? The rule of law as to the time of vesting of a lien on income which has been granted in a mortgage is well established to the effect that the mortgagor is entitled to receive and use the income until the mortgagee shall move to make his lien effective. What must this move of the mortgagee be? In the language of the Supreme Court of the United States, he must either "take personal possession of the mortgaged premises" or "file a bill, have a receiver appointed and possession delivered to him." American Bridge Co. v. Heidlebach, 94 U.S. 798 ( 1876 ). Have the bondholders done either of these things when they merely take over the voting control of the corporation? Is not the mortgagor still in possession of the mortgaged property? The writer can see how a court in a receivership proceeding might apply the letter of the rule as heretofore laid down and hold that the bondholders had failed to make 
The idea of changing the voting control of the corporation for the benefit of different classes of security holders is, of course, not altogether novel, for it is a procedure which has quite generally been adopted by corporations in providing for the issuance of non-voting preferred stock, but it cannot be adopted to solve the problems of holders of fixed obligations without asking and answering certain important questions:

I. Can voting power for the election of directors of a corporation be legally conferred upon the holders of its fixed obligations?

2. If so, how can such voting power be conferred?

3. Can a vote of less than all of the security holders bind the others in any question involving the rights of all?

4. If the income of the corporation, while it is under the management and control of the security holders, should be insufficient to pay operating expenses and fixed charges and to make good past defaults, how are the security holders going to be able to eventually enforce payment of their claims?

5. If the security holders shall take over the voting control of the corporation and either install their own board of directors or elect a majority of the board, are they acting in a fiduciary capacity, so far as the other creditors of the corporation and its shareholders are concerned, so that (a) those in control will be in danger of attack from such junior interests if the results from the operation of the business under their management shall not turn out to be profitable to the corporation, or (b) so that the security holders in control cannot safely participate in a purchase of property from the corporation?

The questions will be discussed in the order in which they have been asked.

I. The law appears to be fairly well established that (a) without the consent of the state a corporation cannot confer voting rights upon the holders of its fixed obligations; ${ }^{8}$ (b) with the consent of the state such voting rights may be conferred, ${ }^{9}$ (c) this consent of the state may be conferred

their lien effective by merely taking over voting control of the mortgagor. At the same time it would seem that a fairly strong argument could be made that the action of the bondholders in taking over the control of the affairs of the mortgagor was equivalent to either taking "personal possession of the mortgaged premises" or "having a receiver appointed" within the spirit of the rule.

${ }^{8} 5$ Fletcher, Cyc. Corp. (perm. ed. I93I), I53, § 2043; 6 Fletcher, Cyc. Corp. (perm. ed. I93I), 635, \$2769.

9 Phillips v. Eastern Ry. Co., r38 Mass. r22, I26 (r884); New England Mut. Iife Ins. Co. v. Phillips, I4I Mass. 535, 6 N.E. 534 (1886); State ex rel. Atty. Gen. v. McDaniel, 22 Ohio St. $354(1872)$. 
by a permissive general statute unless there shall be a provision in the state constitution expressly providing that the voting right shall be in the stockholders; ${ }^{\text {:o }}$ (d) such authority in a corporation to grant voting rights to security holders has been conferred by statute in the following jurisdictions: Delaware, ${ }^{11}$ Louisiana, ${ }^{12}$ Michigan, ${ }^{13}$ Nevada, ${ }^{14}$ Ohio, ${ }^{15}$ and Virginia. ${ }^{16}$

An example of such a statute is section 36 of the General Corporation Act of Michigan, which reads as follows: ${ }^{27}$

"Every corporation formed or existing under this act, may make suitable provision in its articles and thereby, to the extent, in the manner and subject to the conditions provided in the articles, confer upon the holders of any bonds or debentures issued or to be issued by any such corporation, whether secured by mortgage or otherwise, the power to vote in respect to the corporate affairs and management of the corporation to the same extent and in the same manner as shareholders of the said corporation, as may be provided in the articles and, in case of a default in the payment of the principal or interest on such bonds or debentures, or otherwise, or in any other case, confer upon such bondholders or debenture holders the same right of inspection of the corporate books and accounts and records of any such corporation, and also any other rights, which the shareholders of the corporation have or may have by reason of the provisions of the statutes of this state or pursuant to the provisions of the articles."

It seems fairly certain, therefore, that the right to vote at corporate elections can lawfully be conferred upon holders of securities of corporations organized under the laws of any of the above six states and of any other states which may adopt similar legislation, if there be no provision of the state constitution to the contrary. If the corporation in question is organized under the laws of a jurisdiction in which there is no such statutory provision, the desired result can, of course, be effected through a reorganization so as to obtain a new charter under the laws of a state in which such statutory authority exists.

2. When it is authorized by statute how can such right to vote be conferred on the security holders? The answer to this question will depend, of course, to a great extent, upon the terms of the statute.

Under the Michigan act above quoted, and also under the Delaware Act, the grant of voting rights must be made in the articles of incorpora-

30 Durkee v. People, I55 Ill. 354, 40 N.E. 626 (I895).

z Del. Gen. Corp. Law (I93I), § 29.

La. Dart Gen. Stat. (1932), \& Ir2.

${ }^{13}$ Mich. Baldwin's I934 Supp. Comp. Laws (1934), §9978.

${ }^{4}$ Nev. Hillyer Comp. Laws (I930), \$ I 706 .

ss Ohio Throckmorton's Ann. Code (I929), § 8623-77.

${ }^{26}$ Va. Michie Code (1930), § 3808.

17 Mich. Baldwin's x934 Supp. Comp. Laws (I934), \&9978. 
tion. Possibly a corporation may accomplish this by inserting such a general clause in its articles as the following: ${ }^{18}$

"In issuing any bonds or debentures of the corporation the directors may cause the corporation to confer upon the purchasers thereof the right to vote at any or all corporate elections in the manner and to the extent set forth in such obligations or in the trust indenture securing or evidencing the same, provided that the issuance of any such securities have voting rights shall be authorized by vote of the majority of the capital stock of the corporation at a meeting duly called and held."

Conservative counsel, however, would doubtless insist that as to each issue of securities, on the holders of which voting rights are to be conferred, there should be a specific provision inserted in the articles, stating, in detail, the exact rights conferred and the conditions under which such rights may be exercised. This, of course, will necessitate, in the case of every corporation already formed, an amendment of the articles, but that will not be difficult, in view of the fact that a shareholders' meeting will doubtless have been called for the purpose of approving the security issue and the amendment of the articles would be only one additional item of business to be transacted at such meeting.

What should be the terms of such charter provision? If the plan were to vest in the security holders the sole voting power in the event of a default, abundant precedent could be found in those articles of incorporation which provide for the transfer of voting power to holders of preferred shares in the event of a default in the payment of preferred dividends. Inasmuch, however, as the plan is to vest in the security holders the right only to elect a majority of the board of directors, leaving the voting rights of shareholders otherwise unimpaired, we find the problem somewhat more difficult.

One solution would be to grant to each security holder the same voting rights which are held by shareholders, based on the principal amount of securities held (e.g. one vote for each $\$ \mathrm{roo}$ ), the amount being calculated so that the security holders will have a majority control of the meeting if they all attend. A valid objection to such a plan would seem to be that if each security holder should be permitted to vote according to his own inclination there is no certainty that the security holders as a body will be able to elect their majority of the directors, for a minority of security holders, joining in with the shareholders, could continue in office the shareholders' management.

${ }^{18}$ The wording of the Ohio statute on this subject (see supra note 15 ) would seem to indicate that such a general provision in the articles may be contemplated, with the details of the power to be conferred to be set forth in the shareholders' resolution authorizing the security issue. 
Another solution would be to grant to the security holders, voting as a class, the right to elect a majority of the board of directors. The objection to such plan would be that it is too limited in its scope, as there are many other matters on which shareholders are allowed to vote and on which security holders will wish to vote also.

Probably the best solution would be to follow the practice adopted by the Reconstruction Finance Corporation in subscribing to preferred stock in national banks, viz. to grant to security holders, in the event of a default, the right, as a class, to vote on all matters twice the number of votes to which the voting stockholders, as a class, are at the time entitled, each security holder to be entitled to a pro rata share of the votes to which his class is entitled. Such a provision would insure to the security holders, as a class, a two-thirds voting power in the corporation, sufficient to enable them to accomplish all desired ends. It does not insure to the shareholders a minority representation on the board of directors, but wisdom will demand that the security holders exercise their voting power with that in mind.

The provision in the articles will set forth the nature and the length of time of occurrence of the default that will justify the security holders in taking over the voting control, with due provision for the resignation of directors, for the restoration of the voting control to the shareholders after the default shall have been cured, etc., in the same manner as is provided in a well drafted set of articles of incorporation for conferring the right of voting on the holders of preferred shares in the event of a default in the payment of dividends. ${ }^{19}$

Counsel will doubtless cause to be inserted, both in the trust indenture and in the obligation itself, a reference to such provision in the articles, in the trust indenture by a verbatim transcript of the language used in the articles, and in the obligation itself probably by a brief reference to the articles and to the indenture, as granting certain voting rights under certain circumstances prescribed therein.

One very important question to be considered will be as to the manner of providing for collective action by security holders in the event of a default. Who will get them together? How will the voting rights be evidenced? The security holders could be assembled on call by the trustee according to the procedure often found in trust indentures drafted in the Dominion of Canada. ${ }^{20}$ The securities, however, whether they be bonds or debentures, will usually be in bearer form and the trustee will have no

${ }^{19}$ For form of such a clause see I9 Fletcher, Cyc. Corp. (perm. ed. r933), 75, $\$ 8908$.

${ }^{20}$ See I9 Fletcher, Cyc. Corp. (perm. ed. I933), 374-5, § 9155. 
record of the owners except such informal record as is sometimes kept by trustees from the ownership certificates attached to the interest coupons as they are presented for payment. If a real attempt is to be made to reach all security holders, the services will probably have to be enlisted of the banking houses which distributed the securities.

Two courses would seem to be open to such bankers: (I) they could work through the trustee in calling a meeting and seeing that the security holders perfected their own organization, or (2) they could form a protective committee and solicit the security holders to send in to the committee, not deposits of bonds, but proxies, authorizing the committee to vote the securities at any corporate meeting. ${ }^{2 x}$

While theoretically it would seem to be better for the trustee to assemble the security holders and to let them perfect their own organization, experience has demonstrated that such a procedure is rarely successful and that the interests of all will be better served if those who are most deeply interested in working out the rights of the security holders will assume the responsibility of organizing a protective committee, which will devote the time and thought necessary to successfully carry out such work.

How will the right of a security holder to vote be evidenced? He could, of course, bring his bearer obligation to the meeting and exhibit it to the tellers, but that would be both cumbersome and unsafe. A better procedure would be to provide that the register kept by the trustee of the holders of registered securities should be the sole evidence of the right of the security holders to vote. This would require all security holders to change their bonds from bearer form to registered form, but that would not be an extreme requirement to impose..$^{22}$

3. Our next question is as to whether a vote of less than all of the security holders having voting power can be made to bind the whole on any question involving the rights of all.

On further analysis the question is not so much whether action by the majority will bind the whole of the security holders as to their individual

${ }^{2 x}$ By only obtaining proxies the committee will have a somewhat slighter grasp on the control than if they should obtain deposits of securities with a depositary, but, at the same time, by so doing they will probably be able to avoid the expense, delay and red tape entailed in qualifying certificates of deposit under the Federal Securities Act.

${ }^{22} \mathrm{Mr}$. Keeney suggests that where voting rights are to be granted to security holders in the event of default, only registered bonds be originally issued. It is the writer's opinion, however, which has been confirmed by discussion with investment bankers, that the public are so accustomed to bearer bonds that it would seriously affect the marketing of the issue if the bonds were required to be in registered form and that bearer bonds will have to be issued and later changed to registered form if and when the occasion demands. 
rights, but whether a vote of less than the whole of the security holders will bind the corporation legally in taking corporate action in the execution of its lawful powers. The answer would appear to be "yes." If corporate action can be authorized by a vote of less than the whole number of shareholders possessing voting power, there is no reason why such action cannot be authorized by less than the whole of security holders holding voting power. As to whether less than the whole of the security holders can bind the whole number in acquiring corporate assets is a different question, the answer to which will be discussed in considering the next question.

4. Conceding that, in those jurisdictions in which voting rights may be granted to security holders, the comparatively simple procedure above outlined will enable the security holders to take over the management of the corporation and of its property and, out of the rents and income thereof, to make good the defaults on such securities, a much more difficult set of questions is presented when we face the problem of what can and should be done when the results of the operation of the company by the security holders shall not be successful, when the net revenue from operations will be found to be insufficient to make good the defaults. The necessities of the situation will then demand either (a) a sale of the assets of the company as a whole, or (b) a sale of the mortgaged property, if the bonds which are being enforced are secured by mortgage, or (c) a reorganization of the company under some plan which will reduce its fixed charges, relieve it of a burden of unfunded debt and give it new working capital.

Let us consider, first, the matter of a sale of all assets of the company. Assume a corporation with liabilities consisting of first mortgage bonds, $\$ 2,000,000$; unsecured debentures, $\$ 1,000,000$; unfunded indebtedness, $\$ 1,000,000$; preferred stock, $\$ 500,000$; and common stock, $\$ 500,000$. The assets of the corporation have a book value much in excess of the liabilities but can actually be sold for only $\$ 5,000,000$, a purchaser having been found who will offer that amount for the same. Can the property be sold by the corporation for that amount? Will such action require approval of the directors only or must it be approved by any or all of the above parties who will be interested in the proceeds of sale?

Clearly the holders of the debentures and the other creditors of the corporation need not be consulted, for they will be paid in full. The holders of the first mortgage bonds will probably be required to approve the transaction, not because their rights are endangered by the sale, for the proceeds will be sufficient to pay the bonds in full, but because, on general matters, they hold the majority voting rights in the corporation. 
Will it be necessary to consult the preferred and the common shareholders? Quite clearly so, as they still possess voting rights, particularly in those jurisdictions whose statutes provide that a sale of all of the assets of the corporation must be sanctioned by the affirmative votes of all stockholders in the corporation or by an affirmative vote of every class of stockholders, voting separately as a class. ${ }^{23}$

In the same statutes will often be found a provision for the right of a shareholder who shall dissent from such a sale to be bought out at the appraised value of his shares. ${ }^{24}$ Such a provision would not in this case be applicable to preferred shareholders, for they are being paid the full value of their shares and could obtain no greater sum if an appraisal were had. As to the common shareholders, however, the question arises: Can a common shareholder who objects to such a sale demand that he be paid the appraised value of his shares, even though the result of the sale will be to return to him in full the par value of the same? Theoretically the answer to this question would seem to be "yes." Practically, however, it would probably be a difficult matter for any shareholder to convince appraisers that his shares were worth any more than the amount received by him through such a sale unless he were able to show either that, at the time of the sale, he could produce a cash purchaser for the property at a greater price than the sum for which the assets were sold, or that he had a plan for refinancing the corporation which would insure payment of all creditors otherwise than through a sale of the assets.

The above discussion was on the basis that the sale was for an amount sufficient to pay off the creditors and to pay the shareholders in full up to the par value of their shares. If, however, we assume that the sale was for $\$ 4,500,000$, the common shareholders would receive nothing, and, if the sale price were only $\$ 4,000,000$, neither class of shareholders would receive anything. Under such circumstances a majority of either class of shareholders could probably block the sale.

${ }^{23}$ In the following states a sale of all the assets may be authorized by a vote of the stockholders having voting power: Del. Gen. Corp. Law (I93r), § 64a; La. Dart Gen. Stat. (I93I), $\S$ Ix2I; Nev. Hillyer Corp. Laws (I929), § I636; Ohio Throckmorton's Ann. Code (I929), $\S 8623-65$. In Delaware and Nevada, the articles may provide for an affirmative vote of all shareholders or a vote by classes of stock. In Michigan the approval must be by the holders of a majority of the stock issued and outstanding. Mich. Baldwin's r934 Supp. Comp. Laws (1934), § 9999. In Virginia the approval must be by the holders of two-thirds of all of the stock issued and outstanding. Va. Michie Code (I930), $\$ 3820 a$. [Quaere: Are the holders of corporate bonds who have acquired voting control of a corporation by reason of a default in the performance of the corporation to them, "stockholders having voting power," within the meaning of such statutes?]

24 Mich. Baldwin's I934 Supp. Comp. Laws (I934), § 9986; Ohio Throckmorton's Ann. Code (I929), § 8603-72; Va. Michie Code (I930), § 38202 . 
Let us examine into another problem by assuming that the condition of the company is admittedly so bad that $\$ 3,000,000$ is the best price that can be obtained for the assets and that the market price of the outstanding shares of stock is so low that a majority of the stock can be picked up by the purchasers at a song, thereby insuring shareholders' approval. What would be the rights of the debenture holders and of the other unsecured creditors, each of whom will receive only fifty cents on the dollar on his claim? Would such a sale, if made, be in fraud of their rights? Not if the sale is made to a third party and the corporation realizes the best price obtainable, and on this question the burden should be on the party asserting that the price received was so inadequate as to amount to fraud. Therefore, it would appear that a fairly safe procedure could be worked out whereby the corporation would notify the representatives of the debenture holders (who would doubtless have formed a protective committee) and the several other unsecured creditors of its intention to sell the assets, on a named date, for the $\$ 3,000,000$ offered, unless a better offer is received. If, by that date, the objectors have not produced a better offer they should not be in a position to challenge the validity of the sale as being for an inadequate price.

The above discussion has been on the basis that the sale was of all of the assets of the corporation. Let us assume that the mortgaged property constituted only a portion of the corporation's assets. Could the corporation convey good title to a cash purchaser who would offer for the property the amount due on the mortgage debt? Such a sale would not be within the terms of the statutes above mentioned, which are applicable only to sales of all or substantially all of the assets of the corporation, and is within the class of transactions that may be authorized by the board of directors without the necessity of any submission to shareholders for approval. Therefore the only question would seem to be that of the adequacy of the price paid for the property. If care be taken to obtain the highest price that can be had from any person known as desirous of purchasing, and to notify all persons interested-debenture holders, unsecured creditors and shareholders - of the offer made and of the intention to sell at that price unless a higher price is bid, it could well be argued that the validity of the sale could not be later attacked as in fraud of the rights of junior creditors or of shareholders.

Let us assume, however, a still different state of facts. The mortgage is on only a portion of the company's property but there is no outside bidder for the same. The bondholders believe that if they can obtain possession of the mortgaged property they can successfully operate it as an independent unit. The protective committee therefore prepare a plan of reor- 
ganization by which the corporation will sell to the committee or to a corporation organized by it, the property which is mortgaged, in consideration of a surrender and release to the corporation of the obligation on all the outstanding bonds. That such release of liability on the bonds would be a valid consideration for the transfer of the property would seem to be unquestioned. ${ }^{25}$ Whether it would be sufficient consideration would depend, of course, upon whether the value of the property was such as to show a real equity of the corporation in the same over the amount of the indebtedness so released. Again we face a question of fact, as to the adequacy of the price, and again it is suggested that such problem might be met by giving advance notice of the sale to all junior creditors and stockholders with an invitation to better the offer made for the property.

The above plan contemplates, however, a surrender to the corporation of all the outstanding bonds secured by the property released and such a deal cannot well be put through unless all the security holders are united in the purchase or so great a proportion of them that the corporation can call the remainder of the bonds for redemption and deposit with the trustee under the trust indenture the amount due to the non-participating bondholders at the call price, thereby not only protecting the corporation mortgagor against any liability on such non-participating bonds but obtaining from the trustee a formal release of the lien of the trust indenture, so that the reorganized corporation will hold its property free and clear of encumbrances.

If the conclusions reached as to the validity of the last mentioned procedure are correct, it would seem that this might offer an inexpensive plan by which the bondholders might acquire title to the mortgaged property without the difficulties, expense and inconvenience of a foreclosure proceeding.

Assume, however, that the mortgaged property is worth less than the mortgage debt; that there is a substantial proportion of the outstanding bonds which are not represented by the committee and that the committee desire to obtain title to the property by a deed from the corporation and by paying to the trustee, for the benefit of the non-participating bondholders, not the full amount due on their bonds but only such proportion thereof as the actual value of the mortgaged property bears to the whole amount due on the bonds; in other words, by paying to the non-participating bondholders such amount as they would receive if the property were sold at a foreclosure sale at a price equal to its present realizable value. Would such a sale of the property be valid? The answer to that question

${ }_{25}$ Martin v. New Rochelle Water Co., xI App. Div. x77, 42 N.Y. Supp. 893 (I896). 
would undoubtedly be "no"; that the non-participating bondholder is entitled to have the amount due him determined by a judicial sale of the property. Also there is an insuperable practical objection to such a plan in that it contemplates a release by the trustee of the lien of the trust mortgage without payment to the trustee of the whole amount due on the bonds, and the writer does not know of any trustee who would be willing to accept a risk of that nature.

The next question naturally arises. Assuming that the above plan would be invalid as in violation of the contract rights of the bondholders, could it not be made valid by an express provision, clearly set out in the trust indenture and expressly referred to in the bond, that, in the event of a default in the terms of the trust indenture, a protective committee, holding, in good faith, at least two-thirds of the outstanding bonds, should be entitled to bind the bondholders to any plan of reorganization? Or, if it were felt that this attempt to bind the bondholders to any reorganization plan would be too harsh a provision, that the claim of any who should not assent to a reorganization plan proposed by the holders of at least twothirds of the outstanding bonds might be settled in full by depositing with the trustee for the account of such bondholders, an amount of money proportionate to the then present value of the mortgaged property, if it were less than the amount due on the whole of the outstanding bonds? The difficulty would be in obtaining the figure representing such present value of the mortgaged property, for it would not be fair to non-participating bondholders to have that value arbitrarily determined by the reorganization committee. It is not impossible, however, that some method for determining such value might be devised which would be fair to all parties. If so, and if it were thus made a condition of the deal by which the bondholder originally acquired his obligation, there would seem to be reason for the claim that such a reorganization provision might be valid and enforceable.

Let us next assume a case where there are no mortgage bonds outstanding but control is assumed by the owners of unsecured debentures. Is there any method by which these security holders can realize upon the obligations held by them without a judicial sale?

The task which ordinarily confronts a debenture holders' committee in realizing upon the obligations held by them is difficult and serious. All that they can do is to obtain judgment, levy execution against the assets of the corporation and purchase at the execution sale the property so levied upon if no satisfactory outside bid is received for the same. Here, however, they encounter the rights of the other general creditors, over 
whose claims the debentures have no priority and who must be coaxed to join in the plan of reorganization or an arrangement be made to pay them off at a price equivalent to the distributive shares which they would have received on the execution sale. A reorganization, if one is had, will generally have to be worked out in the bankruptcy court through a composition under the bankruptcy law or through a sale of assets by the trustee in bankruptcy.

Can the position of the debenture holders be in any way bettered by a provision granting to them voting rights in the event of default? The practical answer to the above question would seem to depend upon the condition of the corporation as to outside indebtedness at the time the debenture holders take over the voting control. If, at that time, the corporation has no floating debt and is paying current bills, so that the claims of outside creditors are not pressing, the only real default being the nonpayment of interest or principal on the debentures, it would be an excellent procedure for the debenture holders to assume control and to devote the earnings of the corporation, after taking care of current bills, to the making good of the defaults on the obligations held by them.

Should the results from operations be disappointing, however, and should the corporation fail, under such new management, to earn sufficient money, to make good the defaults on the debentures, the holders of the same may ask themselves, "What good does it do us to run this business for the benefit of the shareholders? If we fail, ours will be the loss. If we succeed the most we can get out of it will be the payment of our obligations. The real profit will accrue to the shareholders." In such a frame of mind they may proceed in a number of ways.

(a) They may find a purchaser for the assets of the corporation at a price that will pay the obligations to them. If so, they may have the corporation sell the assets to such purchaser. Whether he will obtain good title would seem to depend upon whether (I) there is any statutory or charter provision requiring consent of a majority or two-thirds of all shareholders to a sale of such assets, and (2) whether those in charge of the corporation protect themselves against a claim that the sale is for an inadequate price by serving notice on all persons interested of the intention of the corporation to sell and by giving to such persons an opportunity to better the sum offered.

(b) They may have the protective committee, as holders of the debentures, sue at law and levy upon the property of the corporation and have the same sold under execution. If at the execution sale, the property goes to an outsider for cash, the cash will be used in paying the debts of 
the corporation, including the indebtedness to the debenture holders. If, however, at such sale there is no outside bid at a price which the committee consider adequate, they may buy in the property in the name of the committee, paying for it in claims and making proper provision for the payment of cash to other creditors and to non-assenting debenture holders, based on their distributive shares of the purchase price. The effect of the procedure would be to leave the debenture holders' committee still in control but with the shareholders eliminated, so that the success of any future operations would be for the sole benefit of the debenture holders.

The last mentioned procedure will, of course, be greatly aided by the fact that the debenture holders are in control of the management of the corporation during the period of the litigation and can carry on the business as before and can see that the corporation does not unduly delay the litigation by any dilatory proceedings or practices.

If, however, at the time the debenture holders decide to take over the management of the corporation under the rights granted to them in the trust indenture, there are claims of other creditors outstanding which are greater in amount than the committee can afford to acquire for the purpose of eliminating controversy, and the claims of any of these outside creditors are in default, so that the creditors are closely watching the affairs of the corporation, any move by the debenture holders to take over the control of the business and, out of the earnings, to make up the defaults due on the debentures, would doubtless be attacked as an attempt to secure a preference and would result in the filing by such outside creditors of an involuntary petition in bankruptcy. In such a case it is apparent that the power granted in the trust indenture to assume voting control of the corporation will be found to have little practical value.

One more problem remains to be considered. Let us assume the same set of facts as in our first hypothetical case where the corporation has outstanding first mortgage bonds, unsecured debentures, unfunded indebtedness and preferred and common stock. Representatives of a majority in interest of all parties concerned, bondholders, debenture holders, creditors and both classes of stockholders, agree upon a plan of reorganization which provides for the property being conveyed to a new corporation under some such arrangement as that the first mortgage bondholders are given an income bond for their old fixed interest obligation, the debenture holders and unsecured creditors are given a preferred stock and the stockholders are given some kind of a junior stock with, possibly, some new first mortgage bonds for a contribution of new capital. Is there any method by which a reorganization of this nature could be worked out without a judi- 
cial sale of the assets of the corporation? Apparently not, for to make such a transfer of assets valid and unassailable from attacks by dissatisfied bondholders, debenture holders, creditors or stockholders would require the concurrence of so many factors that no plan that could be devised would be of practical value.

5. Our remaining question is: "If the security owners shall take over the voting control of the corporation and either install their own board of directors, or elect a majority of the board, are they acting in a fiduciary capacity, so far as the other creditors of the corporation and its shareholders are concerned, so that (a) those in control will be in danger of attack from such junior interests if the results from the operations of the business under their management shall turn out not to be profitable to the corporation or (b) so that the security holders in control cannot safely participate in a purchase of property from the corporation?"

(a) The management of the corporation will be in the directors, who will be charged with the degree of care that is ordinarily expected of directors and, in the opinion of the writer, no greater care, so far as errors of judgment are concerned. Will the fact that all the directors or a majority of them have been elected by a vote of such security holders, rather than by the shareholders, make any difference in the degree of care that will be expected of them? As a matter of law, the answer appears to be clearly "No." As a practical matter and in a court of equity, the writer can see why the acts of such directors might be more closely scrutinized than the acts of directors who have been elected by shareholders. The last named ordinarily represent the utmost junior interest in the property and, therefore, can be expected to conduct the affairs of the corporation for the best interests of all, for only as the rights of senior security holders are first taken care of, bondholders, unsecured creditors, preferred shareholders, will there be anything left for the common shareholders whom such directors most directly represent. On the other hand, the director who represents senior security holders, most often those high in seniority, has less reason to regard the rights of those who occupy a junior position than to look after the rights of those whom he more directly represents. For example, the situation might well be imagined where the corporation, in order to obtain ready cash with which to make a payment on account of principal or interest on bonds held by the security owners then in control, might make a sale of fixed property or of inventory or might enter into a service contract which would be unprofitable to the corporation and ultimately unfair to the junior security holders.

Our conclusion, therefore, might be that the director is under no greater 
legal obligation because of his election by security holders but that, as a practical matter, his acts will be under greater scrutiny and his mistakes of judgment will be more apt to be attacked than if he had been elected by shareholders, particularly if the results of his acts as director are challenged as having been for the unfair advantage of the senior security holders by whom such director was elected.

In an effort to throw more light upon the probable attitude of the courts toward the question under consideration the writer has caused a diligent search of the authorities to be made to see whether there has not been litigation against directors in situations where the voting control of the corporation has passed from common to preferred shareholders under a charter provision therefor. Such search has disclosed but one decided case in which the relationship of preferred shareholders in control of the affairs of the corporation to common shareholders out of control has been discussed.

In that case, ${ }^{26}$ on a reorganization of a railroad following a mortgage foreclosure, preferred shares in a new corporation were issued to the old bondholders and common shares to the old shareholders under a provision that the preferred shareholders should have the sole voting power until the preferred shares had been paid seven successive annual dividends of $7 \%$, whereupon the voting power should revert to the common shares. After several years of operation the common shareholders brought suit to compel the surrender of voting control of the corporation to them, alleging that the earnings of the corporation for seven successive years had been ample to pay all preferred dividends but that the preferred shareholders, in order to retain their control of the management, had paid the preferred dividends only in part and had been applying the income of the corporation to improvements and betterments of its property. The defendant directors contended, among other things, that they owed a duty to the corporation and to the public to put its property in an efficient condition for serving the public and that they were therefore justified in using the income of the corporation for that purpose and that, after all, the declaration of dividends was a matter for the discretion of the directors, with which discretion the courts will not interfere. The court (Jackson, Cir. J.) in granting to the plaintiffs the relief asked for, said:27

"This suit is practically a contest between the two classes of stockholders. The preference class is in control, and is interested in keeping the other out. This result has been so far effected by expending the company's earnings and income in permanently improving the property, or for other purposes than those contemplated by article 4 of

${ }_{26}$ Mackintosh v. Flint \& P.M.H.Co., 34 Fed. 582 (1888). $\quad{ }_{27}$ Supra note 26,6 r2, 6 I3. 
the charter, whereby net income applicable to dividends has been reduced, while the valuation of the company's road-bed and equipment has steadily increased. The preferred class, in control, select the management. This management, or directory, are more than mere agents of the company. They occupy a fiduciary relation towards the unpreferred class of shareholders, in respect to the rights conferred upon them in and by the company's charter. They neglect or deliberately disregard the duties and obligations growing out of such trust relation, and then attempt to shield themselves, or defend their conduct on the ground that they were only discharging the company's duty to the public. The facts of the case do not sanction this defense."

It will be noted that the attack on the directors in the above cited case was not for business losses suffered from poor management, but for an unfair advantage taken by the senior security holders at the expense of those whose rights were junior to them and the decision rendered is more applicable, therefore, to the next subdivision of our question.

(b) Will the security holders who take over the control of the corporation be acting in such a fiduciary capacity to those whose rights are junior to them that they cannot safely participate in a purchase of property from the corporation?

The answer to this question will depend upon the results of the examination into three other questions: (I) the rule in the particular jurisdiction where the corporation is organized as to the validity of a contract made with an interested director, (2) the legal and equitable status of a director elected to represent senior security holders and (3) whether a contract which is voidable per se because made with an interested director can be ratified by those in voting control of the corporation.

(I) On the question whether a contract made with an interested director is voidable merely because of that fact alone, or is voidable only where the contract is shown to have been to the unfair advantage of the interested director is a question on which the courts are not in agreement. A minority of the courts hold that such a contract is voidable per se and the majority hold that it is voidable only if fraudulent. ${ }^{28}$ Many of the courts which recognize the majority rule, however, apply it only if the interested director stands aside and does not undertake to.act for the corporation in negotiating or confirming the contract; but where the interested director participates in the deal or his vote is necessary to authorize it on behalf of the corporation, those courts hold that the contract is voidable, at the election of the corporation, because of the fiduciary relationship alone. ${ }^{29}$ One state, out of the six which provide for giving voting control to the security holders, has clarified this question of the validity of a contract made

${ }^{28} 3$ Fletcher, Cyc. Corp. (perm. ed. I93r), §§ 9r6-92r and cases cited.

${ }^{29} 3$ Fletcher, Cyc. Corp. (perm. ed. I93I), \$§ 922-93I and cases cited. 
with an interested director by a statute on the subject. ${ }^{30}$ In many jurisdictions it is a fairly standard practice, in drafting articles of incorporation, to insert a provision to the effect that no contract made with any director shall be invalid because of that fact alone. ${ }^{3 x}$ Such a clause, which is inserted in the articles of incorporation under the provision, found in most modern incorporation statutes, that the articles may contain "any provision which the incorporators may choose to insert for the . . . limiting and regulating of the powers of the ... . directors," ${ }^{32}$ has generally been regarded by corporation counsel as effective to accomplish the results desired, although they agree with one court that has passed upon the validity of such a clause ${ }^{33}$ that it cannot be used as a cloak for fraud.

(2) The next question that arises is as to what would be the legal and equitable status of a director elected by senior security holders on their taking over the voting control of the corporation.

Such a director might be a thoroughly disinterested person, chosen because of his abilities and sound judgment, and it is possible to conceive that the security holders might persuade public spirited citizens to accept election to such a board. The chances are very strong, however, that the directors who would be elected would be holders of large blocks of the securities in question or the members of a protective committee representing security holders or, possibly, clerks in the offices of the banking firms represented on the protective committee, installed in the directorate because the members of the committee would prefer not to incur the risks attendant upon membership in a board of directors.

If composed of any one of the last named classes of members the directors would be in office to represent the security holders as a group and would owe their chief obligation to that group rather than to the corporation. When, therefore, property is purchased by the protective committee from the corporation there would be slight reason for believing that the transaction would be brought within the line of authorities where the interested director stands aside and lets the deal be concluded with those

30 "No contract of any corporation made with any director of such corporation or with a partnership or other group or association of which any such director shall be a member or with any other corporation of which such director may be a member or director and no contract between corporations having common directors shall be invalid because of such respective facts alone. When the validity of any such contract is questioned, the burden of proving the fairness to the contracting parties of any such contract shall be upon such director, partnership, other group or association, or corporation who shall be asserting the validity of such contract."

${ }^{3 x}$ See Fletcher, Corp. Forms (2d ed. I928), nos. 50, rO3I, I032.

32 Del. Gen. Corp. Law (I93I), § 5(8).

${ }_{33}$ Whalen v. Hudson Hotel Co., I83 App. Div. 316, I70 N.Y. Supp. 855 (rg18). 
who are not themselves interested. It can be expected that all members of the board will be directors interested in the contract under the rule of equity which makes such contracts voidable.

(3) The third and last question under this part of the discussion is whether a contract which is voidable because made with interested directors can be ratified by the corporation by a vote of those who are in voting control.

The answer would appear to be in the negative. Although it is the generally established rule of law that a contract otherwise voidable because of the personal interest therein of a director of the corporation, may, by the shareholders' approval, become valid and binding on the corporation, ${ }^{34}$ the fact cannot be ignored that there is a great difference between ratification by vote of shareholders and ratification by vote of senior security holders who happen at that moment to be in voting control of the corporation. Again, it should be pointed out that the ratification by the shareholders is by the most junior body of security holders, who cannot derive anything from their security holdings until the rights of all other security holders are cared for, whereas ratification by a vote of first mortgage bondholders, for example, who happen to be in voting control of the corporation, is ratification by a senior group, owing no duty to any group but themselves and whose interests may be opposed to the interests of the corporation as a whole, including its shareholders and unsecured creditors.

If the above conclusions are correct, that a purchase of property from the corporation by the group of security holders in control would ordinarily be voidable because of the interest of the directors in such purchase, it would seem that the right of the security holders to take over property for the mortgage debt, without a judicial foreclosure and sale, would be valueless. But is that conclusion altogether correct? There are various matters to be considered in that connection which might give the procedure some value after all.

One is that the corporation in question may have been organized in Michigan, where the statute ${ }^{35}$ which recognizes as valid certain contracts made with directors may be applicable, or it may have been organized in a jurisdiction in which the validity of a charter provision, exempting directors' contracts from attack, in the absence of fraud, is recognized as valid.

Another point is that, under any theory, the transaction which is subject to attack is voidable and not void and can only be set aside by direct

${ }^{34} 3$ Fletcher, Cyc. Corp. (perm. ed. I93x), $\$ \$ 979,982$ and cases cited.

35 See supra note 29. 
attack and a court of equity should be expected, in such a case, to enforce fairly strictly the doctrine of laches. If, therefore, the purchasers shall take pains to notify all of the persons interested of their intention to buy at the price and on the terms named in the notice, so that there can be no claim of a newly discovered right in the shareholder or creditor, it can well be argued that the court would enforce a rule of diligence that would soon confirm, by the doctrine of laches, the title of the purchaser to the property.

One further point to be considered is as to the objective of the security holders. It must be assumed that their desire is not to make a speculative profit from operating the corporation but only to obtain payment of the fixed obligations due them. A court of equity, in entertaining a claim that such a sale should be set aside, can surely be expected to insist that the corporation do equity, by making payment of the obligations due to the security holders whose purchase is attacked, and a sale which is apparently valid and which has been made after due notice to all other persons interested will not lightly be set aside without a showing of the present ability of the corporation to make payment of the obligations due to the security holders who were such purchasers, as a condition of the relief granted.

\section{CONCLUSIONS}

From the above discussion it is the opinion of the writer that the following conclusions might fairly be reached:

I. The right to vote at corporate elections can legally be granted to the holders of fixed obligations of a corporation, if there is statutory provision therefor and no constitutional provision preventing the granting of such right.

2. The power to confer voting rights on the holders of fixed obligations has been conferred by statute in the states of Delaware, Louisiana, Michigan, Ohio, Nevada and Virginia.

3. Any corporation desiring to grant voting rights to holders of fixed obligations, if it is organized under the laws of any other state than the six above named, can accomplish the desired result by reorganizing under the laws of one of such six states.

4. The right to vote should best be conferred in the articles of incorporation and the provision in the articles should probably be specific as to the security to which it is applicable rather than general and permissive.

5. The administrative provisions as to the taking of voting control, the methods of exercise of the same and the relinquishment of control when the desired results have been accomplished are not extraordinarily diff- 
cult to frame, and can be worked out by appropriate clauses in the articles of incorporation, in the by-laws and in the trust indenture under which the fixed obligations are issued.

6. By the use of this procedure the holders of fixed obligations would be able to conserve the business, to prevent waste and to obtain and use for their benefit the rents and income from the corporation or from the mortgaged property without the necessity of a receivership.

7. The procedure for taking over voting control would be particularly helpful in the case where the obligations of the corporation are unsecured debentures, in view of the difficulties encountered in obtaining a receivership under the present procedure.

8. The board of directors who are elected by the security holders of the corporation on their assumption of voting control would probably be held by the courts to occupy a fiduciary relationship to the corporation and to its stockholders and other creditors and all acts of such directors would be closely scrutinized to see whether such security holders were taking unfair advantage of their position. Except as their acts as directors may be alleged to be fraudulently unfair the directors so taking office should be charged with no greater degree of care and should be no more liable for losses in business occasioned by honest mistakes in judgment than if they had been elected by the shareholders.

9. A sale by the corporation to a stranger of a portion of its assets for the purpose of paying obligations due to the security holders in control would probably stand against attack by the corporation, its shareholders or other creditors, if not fraudulent in fact, and if reasonable effort is shown to have been made to obtain the best possible price for the property, particularly if pains are taken to notify all parties interested of the intention to sell and of their opportunity to better the price offered.

Io. A sale by the corporation to mortgage bondholders of property mortgaged for their benefit (where the sale does not convey all or substantially all the assets of the corporation) in consideration of a release of the mortgage indenture, might be legally made under certain circumstances, but, in view of the difficult problems that would have to be encountered, including the necessity for practically unanimous action by the bondholders in making the purchase, such a plan would not ordinarily be found practicable as opposed to the procedure of obtaining title by judicial sale.

II. A sale by the corporation to a stranger of all of its assets for the purpose of paying indebtedness to the security holders in control might legally be made under certain circumstances, but, in view of the many difficult problems that would be encountered, including the necessity in many 
jurisdictions of obtaining the approval of all classes of shareholders, the plan would not ordinarily be found practicable.

I2. A sale by the corporation of all of its assets to security holders of one class or to a reorganization committee representing all classes of security holders would involve the adjustment of so many complicated factors that it cannot be considered practicable as opposed to the apparently more cumbersome but really more effective procedure of judicial sale.

I3. A sale by the corporation of a portion or all of its assets to a group of security holders in control or a sale in which such security holders are interested, even if the same should be declared invalid, might be effective in equity to force the payment of the indebtedness due, in view of the right and duty of a court of equity to order the person complaining to do equity as a condition of the relief granted.

I4. Regardless of whether the realization upon the assets for the benefit of security holders is to be by the procedure of sale by the corporation or by the present procedure of judicial sale, the realization upon the securities will be less difficult and less expensive if the security holders take over the voting control of the corporation, thereby avoiding the necessity of a receivership and thereby preventing unnecessary delays in the proceedings for obtaining a judicial sale.

15. When the security holders take voting control under the power granted to them and proceed to realize upon the assets through the procedure of a judicial sale rather than by a private sale by the corporation, care should be taken in the legal proceedings that are to result in a judicial sale that all formalities of the litigation be complied with, that there be no consent decree and that the complainant be compelled in all instances, to prove the facts necessary to a decree of sale; also that notice of the pendency of the judicial proceeding should be given to junior creditors and to those persons having a substantial stock interest in the corporation. 